\title{
TEACHING DAILY SPEAKING BY USING TELEPHONE THROUGH QUESTION AND ANSWER TECHNIQUE TO THE FIRST GRADE STUDENTS OF DEPARTMENT OF ENGLISH TEACHING IKIP PGRI MADIUN IN THE SCHOOLING YEAR OF 2013/2014
}

\author{
Fitra Pinandhita, S.Pd., M.Pd. \\ IKIP PGRI MADIUN
}

\begin{abstract}
The objectives of this research are: (1) to describe teaching daily speaking by using telephone through question and answer technique, (2) to describe the advantages and disadvantages of teaching daily speaking by using telephone through question and answer technique to the first grade students of Department of English Teaching IKIP PGRI Madiun in the schooling year of 2013/2014.

In this research, the researcher takes five students of $1 \mathrm{~B}$ from the Department of English Teaching IKIP PGRI Madiun as the sample. The researcher uses purposive sampling technique. To get the data, the researcher uses observation, interview, and documentation. In this research, analysis data is done by using descriptive analysis qualitative.

The results of the research are: (1) the use of telephone through question and answer technique in teaching daily speaking to the first grade students of Department of English Teaching IKIP PGRI Madiun is divided into three steps, namely pre- activity, whilst-activity, and post-activity, (2) The advantages of using telephone through question and answer technique in teaching daily speaking to the first grade students of Department of English Teaching IKIP PGRI Madiun are: the use of telephone through question and answer technique in teaching daily speaking can increase students' scores, it makes enjoyable learning, students can focus on teaching learning process, the students have a good chance to practice with their friends in the group. This makes them more active in learning speaking, Last, the use of telephone through question and answer technique increases the students' confidence. Meanwhile, the disadvantages are: the class becomes noisy when the students practice with their friends in the group, and some students have low vocabularies so that the students can not speak fluently.
\end{abstract}

Key Words: Speaking, Telephone, Question and Answer Technique. 


\section{INTRODUCTION}

There are many students of the first grade of Department of English Teaching IKIP PGRI Madiun get problems in learning speaking. In fact, it is often found the inactive situation of teaching learning process in 1B grade of Department of English Teaching IKIP PGRI Madiun. Besides, some of lecturers are lazy to use the best media and method. So, several students get difficulties in teaching learning process. Speaking is the productive skill in the oral mode. Speaking is more complicated than it seems at first and it involves more than just pronouncing words. Interactive speaking situations include faceto-face conversations and telephone calls, in which the speakers are alternately listening and speaking. Besides, the speakers also have a chance to ask for clarification, or repetition from the conversation partners.

Based on the problems above, it is very important and suitable to do this research. The objectives of this research are: (1) to describe the teaching procedures in teaching daily speaking by using telephone through question and answer technique, (2) to describe the advantages and disadvantages of teaching daily speaking by using telephone through question and answer technique to the first grade students of Department of English Teaching IKIP PGRI Madiun in the schooling year of 2013/2014.

Dealing with the condition above, the solution offered was related to the use of telephone through question and answer. Question and answer is one of teaching method that can be used in the classroom. Larsen (2000: 49) gives definition that "This drill gives students practice with answering questions. The students should answer the lecturer's questions very quickly." It means that question and answer is activity that students must answer the question quickly. The lecturer prepares some question for student with variety question about the daily speaking.

Telephone is one of teaching media that should be known by a language lecturer. In this research, the researcher used telephone toy. Telephone toy is telephone made of two cups of mineral drink water which bottoms are connected by a string. Telephone toy includes audio media types. This media can be used in teaching speaking so that the students pretend as if they are talking on the telephone. According to Eliot (2011: 1), "A can-telephone is a device consisting of two cans connected by a string through each base." The definition means that cantelephone is a kind of telephone made of two cans which bottoms are connected by a string. This device is effective to be used in teaching speaking.

\section{RESEARCH METHODOLOGY}

The method of research is designed before conducting the research. In this research, the researcher uses descriptive research method because the researcher describes the facts, the situation and the phenomenon on the using telephone through question and answer technique in teaching daily speaking. Descriptive research is a research which tries to explain the solution of the existed problem based on the data by describing the condition of subject or object of the research (someone, institution, or society) based on the facts at the time of study.

In this research, the researcher uses descriptive qualitative. Qualitative research is a research which describes the fact in real condition. The data is in the form of words or pictures not numbers. The data could be notes, diaries, documentation, etc. which gives description of the fact happen at the time of study. 
This research is intended to describe the using telephone through question and answer technique in teaching daily speaking to the first grade students of Department of English Teaching IKIP PGRI Madiun. In line with the purpose of this research, the appropriate research design is descriptive qualitative.

In collecting data, the researcher uses observation, interview and documentation because it is possible to use more than one method in collecting data. In participant observation the researcher uses active participatory observation. The researcher uses observation to get the data of the research that is done during teaching daily speaking by using telephone through question and answer technique.

Interview is giving some question to be answered by the interviewee in whom it results the information needed for a research. The researcher will formulate some questions to be answered by the English lecturer of IKIP PGRI Madiun and also the sample of the research. Interview to English lecturer will be held only after using telephone through question and answer technique in teaching daily speaking. Meanwhile, interview to the samples will be conducted twice. It is before and after using telephone through question and answer technique in teaching daily speaking.

In conducting this research, the researcher gets some documentation based on the field notes, they are: syllabus, RPP, lesson plan and the first graders' score of IKIP PGRI Madiun. Menwhile, data analysis technique is a stage to process the data before stating it to another person. It creates a condition in which the researcher has an authority to choose some techniques of analyzing the data. The researcher uses three steps of data analysis technique. They are data reduction, data display, conclusion and verification.
There are some procedures of the research: planning, application, and reporting. In the step of planning, the activities are preparing anything needed for the research, like observing the location of the research. In the step of applying the research, the researcher starts to collect the data and analyze them. In the step of reporting the research, the researcher writes a report of the research systematically in a form of research.

\section{RESEARCH FINDINGS AND DISCUSSION}

In data presentation the researcher presents the result of collecting data. The data of the research are collected by applying observation, documentation, and interview. The researcher uses observation to know the process of teaching daily speaking by using telephone through question and answer technique for the $1 \mathrm{~B}$ grade students of Department of English Teaching IKIP PGRI Madiun in the schooling year of 2013/2014. Besides, observation has purpose to know the activities of lecturer and students during teaching learning process based on the lesson plan, RPP and syllabus. The researcher also uses interview specifically free-guided interview to collect the data. Through the interview, the researcher got the data related to the advantages and disadvantages of using telephone through question and answer technique. Then, the last is the documentation has purpose to get the data accurately. It includes the syllabus, RPP, lesson plan, student's score, photos of teaching learning process, etc. The result of this research are as follows:

1. Teaching Procedures in Teaching Daily Speaking by Using Telephone through Question and Answer Technique to the First Grade Students of Department of English 
Teaching IKIP PGRI Madiun in the Schooling Year of 2013/2014

It is proved by the result of observation, the researcher found there were three activities in teaching learning process in teaching daily speaking by using telephone through question and answer technique. It is also proved by the documentation. Teaching procedures of teaching process in teaching daily speaking by using telephone through question and answer technique. Teaching daily speaking by using telephone through question and answer technique was applied by lecturer at the whilstactivities.

2. The Advantages and Disadvantages of Teaching Daily Speaking by Using Telephone through Question and Answer Technique to the First Grade Students of Department of English Teaching IKIP PGRI Madiun in the Schooling Year of 2013/2014

There are some advantages of using telephone through question and answer technique in teaching daily speaking to the first grade students of Department of English Teaching IKIP PGRI Madiun in the schooling year of 2013/2014 which are found by the researcher after conducting this research. They are as follows: the use of telephone through question and answer technique in teaching daily speaking can increase students' scores; the use of telephone through question and answer technique makes enjoyable learning; students can focus on teaching learning process; the students have a good chance to practice with their friends in the group. This make them more active in learning speaking; the use of telephone through question and answer technique increases the students' confidence. Besides, the researcher also found several disadvantages. They are as follows: the class becomes noisy when the students practice with their friends in the group; some students have low vocabularies so that the students can not speak fluently.

\section{CONCLUSION}

The conclusions of this research are as follows: The advantages of the use of telephone through question and answer technique in teaching daily speaking to the first grade students of Department of English Teaching IKIP PGRI Madiun consists of five points. First, the use of telephone through question and answer technique in teaching daily speaking can increase students' scores. Second, the use of telephone through question and answer technique makes enjoyable learning. Third, students can focus on teaching learning process. Fourth, the students have a good chance to practice with their friends in the group. The students more active in learning speaking. Last, the use of telephone through question and answer technique increases the students' confidence.

Meanwhile, the disadvantages are: First, the class becomes noisy when the students practice with their friends in the group. Second, some students have low vocabularies so that the students can not speak fluently. 


\section{REFERENCES}

Arief S. Sadiman, et al. 2006. Media Pendidikan. Jakarta: Raja Grafindo Persada.

Berg, Bruce L. 2009. Qualitative Research Methods for the Social Sciences. United States of America: Pearson Education.

Bogdan Robert C. and Biklen Sari Knopp. 2007. Qualitative Research for Education An Introduction Theories and Methods. United States of America: Pearson International Edition.

Bourner, Tom. 1997. Teaching Methods for Learning Outcomes. MCB University Press. Journal Education + Training (Online), Volume 39, No. 9, (http://www.google.com/Tom+Bourner+T eaching+Methods+for+language+ outcomes.pdf, accessed on January $15^{\text {th }}$ 2014).

Blosser, P.E. 2002. How to Ask the Right Questions. (Online), (http://www.google. com/questiontypes.pdf, accessed on January $15^{\text {th }} 2014$ ).

Brown, H. Douglas. 2001. Teaching by Principles and Interactive Approach to Language Pedagogy. London: Longman by Pearson Education, Inc.

2004. Language Assessment Principles and Classroom Practices. USA: Longman by Pearson Education, Inc.

Brown, James Dean and Rodgers, Theodore S. 2002. Doing Second Language Research. China: Oxford University Press
Burhan Bungin.2007. Penelitian Kualitatif. Jakarta: Putra Grafika.

Doff, Adrian. 1990. Teach English A Training Course for Lecturers. The British Council: Cambridge University Press.

Edge, Julian. 2001. Essentials of English Language Teaching. New York: Longman Publishing.

Eliot, Thomas. 2011. Frequency and Transmission Intensity in a CanTelephone. ISB Journal of Physics (online), (http://www.isb.ac.th/HS/JoP/index.html, accessed on January $15^{\text {th }} 2014$ )

Gabriel Amin Silalahi. 2003. Metodologi Penelitian dan Studi Kasus. Sidoarjo: Citra Media.

Goodwyn, Andrew. 1992. English Teaching and Media Education. United States of Amerika: Open University Press.

Gray, Peter. 2011. The Human Nature of Teaching I: Ways of Teaching That We Share With Other Animals. (online), (http://www.psychology.com, accessed on January $15^{\text {th }}$ 2014).

Hadari Nawawi. 2005. Metode Penelitian Bidang Sosial. Yogyakarta: Gadjah Mada University Press.

Harmer, Jeremy. 2007. The Practice of English Language Teaching. England: Longman Pearson Education Limited.

Hendyat Sutopo. 2005. Pendidikan dan Pembelajaran Teori Permasalahan dan Praktek. Malang: Univeritas Muhammadiyah Malang. 
Hedge, Tricia. 2007. Teaching and learning in the Language Classroom. New York: Oxford University Press.

Hujair AH. Sanaky. 2009. Media Pembelajaran. Yogyakarta: Safiria Insania Press.

Husaini Usman and Purnomo Setiady Akbar. 2004. Metodologi Penelitian Sosial. Jakarta: Bumi Aksara.

Joko Subagyo. 2004. Metode Penelitian Dalam teori dan Praktek. Jakarta: Rineka Cipta.

Johnson, Andrew P. 2005. A Short Guide to Action Research. United States of Amerika: Pearson.

Kauchak, Donald P and Eggen, Paul D. 2007. Learning and Teaching Research-Based Methods.United States of America: Person Education, Inc.

Larsen, Diane and Freeman. 2000. Tecniques and Principles in Language Teaching. New York: Oxford University Press.

Leu, Elizabeth. 2005. The Role of Lecturers, Schools, and Communities in Quality Education A Review of the Literature. United States of America: Academy for Educational Development Global Education Center. (online), (http://www.google.com/search=Elizabet h+Leu+The+Role+of+Theacher.pdf, accessed on January $15^{\text {th }} 2014$ ).

Louma, Sari. 2004. Assesing Speaking. New York: Cambridge University Press.

Lunenburg, Fred C. 2011. Theorizing about Cirriculum: Conceptions and Definitions. International Journal of Scholarly Academic Intellectual Diversity (Online), Volume 13, No. 1, (http://www.google.com/Fred+C.+Lunenb urg+
Theorizing+about+CurriculumConception tand+Definition+International+journal+o $\underline{\mathrm{f}+\text { Scholarly+academic+intelectual+diversi }}$ ty.pdf, accessed on January $15^{\text {th }} 2014$ ).

McDonough, Jo and McDonough, Steven. 2004. Research Methods for English Language Lecturers. London: Arnold, A member of the Hodder Headline Group.

Malawi. 2004. Participatory Teaching and Learning A Guide to Methods and Technique. (online), (http://www.google.com/url?q=http://pdf .usaid.gov/pdf, accessed on January $15^{\text {th }}$ 2014).

Markley, Tim. 2003. Defining the Effective Lecturer: Current Arguments in Education. (online), (http://www.google.com/search=Definin g+the+Effective + LecturerCurrent+Arguments+in+Educa tion+Tim+Markley+White+Mountains+ Regional+District+New+Hampshire.pdf, accessed on January $15^{\text {th }} 2014$ ).

Margono. 2004. Metodologi Penelitian Pendidikan. Jakarta: Rineka Cipta.

Murcia, Marianne Celce. 2001. Teaching English as a Second or Foreign Language. United States of Amerika: Thomson Learning, Inc.

Norton, Donna E. and Norton, Saundra E. 1994. Language Arts Activities for Children. United States of America: Merrill is an Imprint of Macmillan College Publishing Company.

Nunan, David. 2003. Practical English Language Teaching. New York: Cambridge University Press.

Ricards, Jack C and Rodgers, Theodore S.2001. Approach and Methods in Language 
Teaching. Manoa: Cambridge University Press.

Richards, Jack C and Renandya, Willy A. 2002. Methodology in Language Teaching. USA: Cambridge University Press.

Sagers et al. 2010. The tin-can telephone: An example of sound propagation and communication for Project Listen Up. Proceedings of Meetings on Acoustics (online), volume 9, (http://asadl.org/poma/resource/1/pmarcw/v9// p025002, accessed on January $\left.15^{\text {th }} 2014\right)$.

Sierra, Fernando Cerezal. 2011. Foreign Language Teaching Methods: Some Issues and New Moves. (Online), (http://www.google.com/search=Fernando + Cerezal

+ Sierra + Foerign + Language + Teaching $+\mathrm{M}$ ethods+Some+Issues+and+New+Moves.p df, accessed on January $\left.15^{\text {th }} 2014\right)$.

Smaldino, Sharon E., et al. 2005. Instructional Technology and Media for Learning. United States of Amerika: Pearson Education, Inc.

Sunarko.2003. Pendekatan dan Metode Pembelajaran Geografi. Jakarta: Direktorat Pendidikan Lanjutan Pertama. Direktorat Jendral Pendidikan Dasar dan Menengah. Departemen Pendidikan Nasional.

Sugiyono. 2009. Metode Penelitian Pendidikan Pendekatan Kuantitatif, Kualitatif dan $R$ $\& D$. Bandung: Alfabeta.

Suharsimi Arikunto. 2010. Prosedur Penelitian Suatu Pendekatan Praktik (Edisi Revisi 2010). Jakarta: Rineka Cipta.

S.Nasution. 2004. Metode Research (Penelitian Ilmiah). Jakarta: Bumi Aksara.
. 2003. Metode Penelitian Naturalistik - Kualitatif. Bandung: Tarsito.

Syafarudin and Irwan Nasution. 2005. Manajemen Pembelajaran. Jakarta: Quantum Teaching.

Syaiful Bahri Djamarah dan Aswan Zain. 2002. Strategi belajar Mengajar. Jakarta: Rineka Cipta. 